\title{
Evaluation of Bacterial Contamination of Beef Carcasses in Namwala and Lusaka Districts, Zambia
}

\author{
Wizaso Mwasinga ${ }^{1,2 *}$ John B Muma ${ }^{1}$, Clovice Kankya², Chisoni Mumba1, \\ and Musso Munyeme ${ }^{1}$ \\ ${ }^{1}$ Department of Disease Control, School of Veterinary Medicine, University of Zambia, Lusaka, Zambia \\ ${ }^{2}$ Department of Biosecurity, Ecosystems and Public Health (BEP), College of Veterinary Medicine and \\ Animal Resources and Biosecurity (COVAB), School of Biosecurity, Biotechnical and Laboratory Sciences \\ (SBLS), Makerere University, Uganda \\ *Corresponding author: Wizaso Mwasinga, University of Zambia, School of Veterinary Medicine, \\ Department of Disease Control, P.O. Box 32379, Lusaka, Zambia \\ Email: wizanso14@gmail.com ,+260979758029 \\ DOI: https://doi.org/10.53974/unza.jabs.5.1.490
}

\begin{abstract}
Background: Abattoirs have been purported to be ideal areas were possible microbial contamination of meat products is likely to occur. A total of 314 food of animal origin, mainly, beef, has been identified as a source of dietary protein for humans albeit it being a source of food-borne diseases including zoonoses. This study was carried out to evaluate bacterial contamination and the risk factors associated with contamination of beef carcasses during processing.
\end{abstract}

Methods: A total of four abattoirs were sampled within three months with one in Namwala and three in Lusaka districts. 314 beef carcass surface swabs were obtained from the neck region by swabbing the carcasses, immediately after evisceration and after washing.

Results: The results of mean total viable counts (TVC) of carcass contamination were enumerated as the mean $\log$ from $4.7 \log _{10} \mathrm{cfu} / \mathrm{cm}^{2}$ in an abattoir where Hazard Analysis and Critical Control Points (HACCP) practiced to $5.8 \log _{10} \mathrm{cfu} / \mathrm{cm}^{2}$ in abattoirs without HACCP.
Bivariate analysis showed a significant difference in carcass contamination when town abattoirs (Lusaka) were compared with rural ones (Namwala); $\chi^{2}=43.87, \quad \mathrm{P}<0.0001$. Multiple logistic regression analysis identified poor hygiene practices, the absence of antemortem inspection, and lack of Hazard Analysis and Critical Control Points (HACCP) implementation as significant factors associated with carcass contamination.

Conclusion: The microbial load of the fresh beef carcasses in Namwala district was higher than that in Lusaka district as determined by the Total Viable Count. This is an indicator that beef is being produced under poor abattoir hygiene conditions. Therefore, beef carcasses with high bacterial loads are potential sources of foodborne pathogens leading to foodborne disease, hence, there is need for advocating for good hygiene practices in the abattoirs.

\section{Keywords}

Beef carcass; microbial contamination; good hygiene practices; hazard analysis and critical control points (HACCP). 


\section{Introduction}

The current global trend of heightened awareness and increased scrutiny by consumers, and an ever-increasing demand for safe and quality food globally is a significant public health issue. The safety of meat and other foods of animal origin, in the 21st century, remain a critical public health concern not only for developing but also for the developed world, particularly, under the concept of one health. Food-borne diseases have been shown to contribute substantially to morbidity and mortality rates, worldwide especially in resourcelimited Countries [1]. The deleterious impact of these diseases on human health, concurrent with the associated socioeconomic cost, has led to an increased demand for the production of safer, sound and wholesome foods globally [1]. In many parts of the world, beef which has been shown to make up a considerable portion of a typical human diet has also been identified as one of the primary vehicles of food-borne diseases [2]. The World Health Organisation (WHO) has identified non-typhoid Salmonella, Escherichia coli, Staphylococcus aureus and thermophilic Campylobacter as some of the zoonotic food-borne pathogens of importance $[2,3]$. Furthermore, these pathogens have been observed to develop resistance to antibiotics that are used for treatment of human and livestock diseases [4].

Food of animal origin, especially beef, has been shown to have a higher risk of being contaminated by microbes if handled in an unhygienic manner $(5,6)$. This contamination by microorganisms can be attributed to the slaughter stock themselves (hides, hair, intestinal contents and around the lymph nodes), the environment (water, manure, flies, rodents) and external sources such as handlers [7,8]. Foodborne diseases are caused by the ingestion of contaminants present in food. It is, therefore, of paramount importance that food is handled in the most hygienic manner to prevent it from being contaminated by microorganisms, especially bacteria [9]. It is also critical to monitor bacterial levels contaminating these carcasses, and this can be done using techniques such as Total Viable Counts (TVC), Total Coliform Counts (TCC) and Total Faecal Counts (TFC) . Knowing bacterial load of carcasses is known to assist in developing a system that evaluates the quality of carcasses in a processing plant.

In Zambia, particularly in Lusaka district, there has been an increased demand for beef and beef products due to the increasing population size despite the small and underdeveloped beef market [11]. With the increasing population size and high demand for beef and beef products, domestic beef production in both the commercial and traditional sectors is increasing significantly. The traditional sector accounts for about 80 per cent of the cattle population in Zambia [12]. Most of the beef consumed undergoes some form of processing at local abattoirs or slaughter shelters. Namwala district has the highest cattle density in the entire Nation of Zambia [13]. Beef from this district is not only consumed locally but finds its way to lucrative markets in the bigger cities such as Lusaka. Alonge (1991), defined an abattoir as a premise approved and registered by the controlling authorities for hygienic slaughtering and inspection of animals, processing and effective preservation and storage of meat products for human consumption [14].

In the recent past, diarrhoeal diseases related illnesses linked to foodborne infections have been recorded as some of the major causes of morbidity both among adults and children in Zambia 
[15]. Currently, diarrhoea is ranked as the third most important cause of morbidity and mortality among all age groups and the top ten cause of death with estimations that forty children die every day from dehydration caused by severe diarrhoea as a result of bacterial pathogens such as E. coli and Rotavirus (16-18). Furthermore, according to local authorities, under the Public Health Department, some abattoirs and meat processing plants have continued to process meat under some unhygienic conditions and practices $(19,20)$. Most of such abattoirs have been shown to be finding challenges in implementing effective Hazard Analysis Critical Control Points (HACCP) programmes yet alone to conduct good hygienic practices [21]. In a study in which the Hazard Analysis Critical Control Point (HACCP) concept was applied to four for the first time, Zambian cattle slaughterhouses, it was concluded that there is a need to establish slaughter and dressing procedures, and quality assurance programmes based on risk assessment and maximum utilisation of resources [21].

Given that the majority of Zambians are likely to consume beef, it is, therefore, imperative to assess the levels of bacterial contamination of beef carcasses processed at selected abattoirs in Namwala and Lusaka districts. Furthermore, this study aimed at gathering information on risk factors and practices that might influence bacteriological contamination of beef carcasses during production.

\section{Materials and Method}

\subsection{Study Design and Site}

A cross-sectional study was carried out from November 2015 to February 2016. This study was conducted at beef abattoirs in Lusaka and Namwala districts respectively.

\subsection{Study Population}

The target study population consisted of all animals that were slaughtered at the abattoir during the period of the study, and the study unit of interest was a dressed beef carcass, which presented a primary sampling unit. For the bacteriological sampling, Systematic Random Sampling (SRS) method was applied. At least, a minimum of four people were interviewed at each premise, that is one from management and three food handlers along the production line.

\subsection{Sample Size}

The sample size for bacteriological analysis was calculated according to abattoir throughputs as follows: since there were four significant abattoirs in total, the animals slaughtered in these abattoirs made up the target population $(N)$, from which a sample population (n) was drawn. The sample size was calculated using the formula:

$n=\frac{\mathrm{x}^{2} \mathrm{NP}(1-\mathrm{P})}{\mathrm{d}^{2}(\mathrm{~N}-1)+\mathrm{x}^{2} \mathrm{P}(1-\mathrm{P})}$

A total of 151 carcasses were randomly selected from the four abattoirs for bacteriological examination.

Then, since the daily mean throughputs of the abattoirs were Abattoir $\mathrm{A}=15$, Abattoir $\mathrm{B}=8$, Abattoir $\mathrm{C}=50$ and Abattoir $\mathrm{D}=40$, using the ratios of the above, the carcasses sampled from the abattoirs was Abattoir $\mathrm{A}=$ 20, Abattoir $\mathrm{B}=11$, Abattoir $\mathrm{C}=67$ and Abattoir D = 53. Abattoir A, B and D were located in Lusaka whilst Abattoir C was in Namwala.

\subsection{Sample Collection and Processing}

Sampling was carried out by swabbing the muscular surface of forequarter and the neck of each carcass at two process points (immediately after evisceration and washing) as follows: A screw- 
capped test tube, containing 0.1 per cent peptone water and a sterile swab was opened aseptically by first flaming the mouth of the test tube using a spirit lamp. Then an area of $100 \mathrm{~cm}^{2}$ marked with a sterile frame of $10 \mathrm{~cm} \times 10 \mathrm{~cm}$ on each site of the carcass was rubbed using the sterile swab for thirty seconds and the swab was put back into a screwcapped test tube containing $10 \mathrm{ml}$ of sterile maintenance medium $(0.85 \%$ $\mathrm{NaCl}$ and $0.1 \%$ peptone). After this, the mouth of the test tube was flamed using a spirit lamp and tightly closed. The tubes were then transported to the University of Zambia, Department of Disease Control microbiology laboratory at $+4^{\circ} \mathrm{C}$ in a cool box and processed for further analysis. In the laboratory, all media was prepared according to the manufacturer's instructions.

Aerobic Plate Count (APC) was carried out on total plate count agar (HiMedia laboratories Pvt, Mumbai, India). The medium was prepared according to manufacturer's instructions. Samples were serially diluted and an aliquot of $1 \mathrm{ml}$ of each of serial dilution was transferred to the petri dish (4 inch diameter) with solid agar. A glass spreader was used to uniformly spread the $1 \mathrm{ml}$ aliquot into the media. Plates were incubated at $37^{\circ} \mathrm{C}$ for twenty-four hours. After incubation, APC was determined from appropriate plates.

\subsection{Risk Factors Data Collection}

A checklist and structured questionnaire were developed to address data on factors and practices associated with bacteriological contamination such as cleaning and disinfection procedures, process flow, abattoir design, carcass processing inclusive of separation, HACCP application and hygiene training. The questionnaire was pretested in Namwala district, to help refine its strengths and weaknesses so as to enable collection of reliable information. To ensure collection of quality data, two research assistants were trained as enumerators by the lead researcher. Furthermore, the research assistants were observed interviewing three respondents in the presence of the lead researcher, before they were allowed to conduct interviews on their own. Interview schedules were designed for abattoir management and abattoir operatives.

\subsection{Data Management and Analysis}

The questionnaire data was categorised, coded, summarised and entered manually into Microsoft Excel ${ }^{\circledR}$ by the lead researcher. The data was further cleaned by counter checking for correct codes and respective cells for missing variables in Microsoft Excel ${ }^{\circledR}$ before exporting it to STATA Version 12. Analysis of qualitative data collected through closed-ended questions involved listing data for each question, establishing categories and finding a label for each category. Data analysis involved the use of frequency counts for each variable and Chi-square tests were performed. Data generated was analysed using STATA Version 12. Survey summary and descriptive statistics were calculated. A 95 per cent confidence interval $(\mathrm{CI})$ and $p$ values $(p \leq 0.05)$ were used to test for statistical differences across strata. Further, analysis to identify modifiable risk factors was performed using STATA. A logistic regression analysis was conducted to determine the strength of association between abattoir risk factors. Bacteriological data collected from the laboratory was analysed by comparison with the set standards on bacteriological contamination of beef, that is both local and international standards. 


\section{Results}

\subsection{Bacterial Total Viable Counts}

Total Viable Counts (TVC) were performed on 314 carcass swabs from a total of four abattoirs and the overall mean was $\log 10$ $5.09 \mathrm{cfu} / \mathrm{cm}^{2}$. The results indicated that abattoir $\mathrm{C}$ had the highest mean TVC, which was $\log _{10} 5.64 \mathrm{cfu} / \mathrm{cm}^{2}$ while Abattoir D had the lowest mean TVC of $\log _{10} 4.55 \mathrm{cfu} / \mathrm{cm}^{2}$ as shown Table 1.

A comparison of the TVCs at two process points (after evisceration and after washing) in the abattoirs was also done, and the results from the study indicated that TVC increased significantly in abattoir $\mathrm{C}(\mathrm{p} \leq 0.0285)$ and $\mathrm{D}(\mathrm{p} \leq 0.0077)$ after the carcass was washed. Table 2 shows the distribution of mean $\log _{10} \mathrm{cfu} / \mathrm{cm}^{2}$ at the two processing points.

\subsection{Comparative Assessment between}

\section{Abattoirs in Namwala and Lusaka} Districts

A comparison of carcass contamination in the two districts (Lusaka and Namwala) was performed, and the results indicated that there was a significant difference regarding carcass contamination across the two districts. Abattoirs in Lusaka were compared with those from Namwala district, $\chi^{2}=43.87, \mathrm{P}<0.0001$. The results are outlined in Table 3.

\subsection{Assessment of Abattoir Risk Factors for Bacterial Contamination}

Some risk factors among them: cleaning of work surfaces, type of disinfection method used, the performance of antemortem inspection, the frequency of antemortem inspection, the composition of the HACCP team, and the frequency that the HACCP system were significantly related to contamination $(p<0.05)$. This information is outlined in Table 4.

The abattoirs which had no HACCP plan and team in place were nine times more likely to have higher levels of contamination, than those with a HACCP plan and team in place $(\mathrm{OR}=8.9,95$ per cent $\mathrm{CI}$; $5.3 \%-15.1 \%$ ) given that types of disinfection, examination of abattoir workers, performance of antemortem examination as well as wearing of clean protective clothing are controlled. The model explained and correctly classified 76 per cent of the variables under consideration. Poor hygiene practices, the absence of antemortem inspection, lack of HACCP implementation, lack of personal protective equipment were associated with an increased likelihood of bacterial contamination of carcasses. The other factors that were highly significant in the final model are represented in Table 5.

\section{Discussion}

In a beef processing industry, bacterial contamination of carcasses and beef products is a consequence that cannot be avoided, but efforts can be put in place to reduce the levels of contamination. Good hygiene and food safety practices during the process flow help in achieving minimal bacterial contamination of the carcasses as well as beef products (21, 22).

This study has found numerical and statistically significant differences in the overall microbial contamination of carcasses produced mostly under unhygienic conditions specifically in abattoirs that did not have a HACCP plan. Similarly, in a study in Ethiopia, it was indicated that abattoirs that had HACCP system implemented had lower risk of carcass contamination compared to those that did not have one in place [23]. The lack of effective implementation of HACCP programs in most abattoirs was one of the most critical factors that were 
found to significantly affect the balance between a "clean" and "dirty" abattoir. This indicates that acceptable level of carcass hygiene is likely to be maintained in abattoirs that practice HACCP system than in those that don't. This was augmented by the finding that abattoirs which had no HACCP plan and team in place were nine times more likely to have higher levels of contamination, than those that had. It can be argued that microbiological contamination of carcasses should be adequately controlled in the food plants by monitoring of the process flow and hygiene during slaughter. This is essential in that it is a way of verifying if the HACCP system in the food plant is efficient [24]. Despite all abattoirs claiming to have a HACCP implementation plan in place, not all of them had the HACCP plan, and some had no HACCP team in place. Given the levels of contamination at abattoir $\mathrm{C}$ of Namwala district, it is evident that HACCP was poorly implemented or even absent. In abattoirs, it is crucial to implement and monitor HACCP because it assists in reducing the level of bacterial contamination of carcasses. A study by Muma J. B. et. al, [21], indicated that high levels of carcass contamination were as a result of the slaughter and dressing procedures and low hygiene in the slaughterhouses. The slaughter and dressing procedures are essential critical control points (CCP's) in the process flow of beef production at abattoir level.

From our current findings, it is important to have a sanitation program in place in an abattoir. This sanitation program ensures that there are effective cleaning and disinfection of the abattoir and abattoir environment. When scraps of tissue, horns, faeces and other solid wastes are left to accumulate in the environment, a habitat for rodents and other pests is created. The result is a risk of contamination of the abattoir environment with pathogens that are carried by these pests and rodents [25]. When it comes to bacterial contamination, TVC's of beef carcasses are used to estimate general abattoir hygiene. FAO, recommends that TVC's obtained from meat carcass surfaces should not exceed 100,000 per gram $(105$ per $\mathrm{cm} 2)$ which is equivalent to $\log 105.0 \mathrm{cfu} / \mathrm{g}$ [26]. From the present study, the result of the general mean TVC is slightly above the acceptable range of surface carcass contamination, and it can, therefore, be said that the carcasses are in a critical microbiological condition. Hence this sends an alarm signal that there is urgent need to improve meat hygiene along the slaughter process and general abattoir hygiene. Knowing bacterial load of carcasses is known to assist in developing a system that evaluates the quality of carcasses in a processing plant.

Comparison of TVC'c after evisceration and after washing is an indicator of contamination that may arise as a result of external or intrinsic factors [27].. There was no increase in TVC after washing in Abattoir B because it had good hygienic practices and also a good HACCP plan and team in place. A study by Galland J.C. [28], attributed an increase in bacterial contamination levels after washing to probable contamination in the water source. Pressure washing of carcasses with hot or cold water is an effective method of reducing bacterial load on carcasses; however, this depends on the quality of the water, the amount used and the pressure at which the water is applied to the carcass. Washing of carcasses is a good hygiene practice but may lead to the spread of the bacteria from one surface area to another [23]. One critical observation was that in some 
abattoirs, a brush was used on the carcass surface during washing and this is likely even further to contaminate the carcasses if it was not sterilized before washing each carcass.

Our study indicated that different abattoirs employed different methods of disinfection with $55 \%$ of the respondents saying they used both hot water and chemicals for disinfection, while $45 \%$ used chemicals only. However, there was no plausible explanation for the numerical difference in the cleaning and disinfection methods. Nevertheless, in all abattoirs, hot water was used as a sterilizing agent for equipment used during the slaughter process and hence is essential. Reduction of contamination to the carcasses requires that chemical and physical treatments be applied to environmental surfaces and equipment within the abattoir. Depending on the target area for disinfection, i.e. equipment or facilities, hot water/steam and chemicals may be used for decontamination/disinfection. This is usually preceded by methods of cleaning such as removal of physical dirt, application of water and then cleansing using a detergent (chemical) followed by rinsing with clean water [29].

When abattoir contamination was assessed across different slaughterhouses, a significant difference regarding general contamination was noticed between urban (Lusaka) and rural (Namwala) abattoirs district $(\chi 2=43.87$, $\mathrm{P}=0.0001)$. The abattoir of Namwala district (denoted as C), had higher TVCs than those of Lusaka district and this was attributed to failure to adhere to HACCP and poor hygiene practices such as workers in dirty working gear. The total viable counts expressed as mean $\log \mathrm{cfu} / \mathrm{cm} 2$ in the abattoirs $\mathrm{A}$, $\mathrm{B}, \mathrm{C}$ and $\mathrm{D}$ was $4.93 \pm 0.85,4.69 \pm 0.81$, $5.64 \pm 0.65$ and $4.55 \pm 0.61$ respectively.
HACCP has been recommended by many stakeholders such as FAO to be used for bacteriological quality control of meat in abattoirs. HACCP was initially developed to provide safe food for human consumption [30]. Remotely, the lack of enforcement and regulatory monitors as shown in the number of abattoir operatives not having had been medically examined is another critical risk factor for exposure. It is vital that all abattoir workers undergo frequent medical checkups because most abattoir workers handle the carcasses with bare hands and are in close contact with the carcasses. Worker hygiene regarding wearing clean personal protective equipment is also an essential factor when it comes to microbiological contamination of carcasses. Results from our study revealed that $67.5 \%$ of the abattoir workers were wearing clean working attire whilst $32.5 \%$ were not wearing clean working attire. Other literature states that when dirty protective wear is worn, the quality of meat produced is questionable because dirty protective wear is a probable source of microbes that contaminate the carcasses [25,31,32]. For good quality beef production, food handlers should wear clean protective clothing that covers their bodies and hair. Hand washing should be performed at regular intervals $[33,34]$.

Although abattoir hygiene practices play a more critical role in production beef carcasses safe for human consumption, it is important that pre-slaughter strategies and post-slaughter strategies such as antemortem and postmortem inspection must be performed. Visual inspection of the animals before slaughter helps to identify the animals with a dirtier hide from those with a clean hide. Bacterial contamination of the carcass following skinning is associated with a dirty 
hide, and it assumed that animals with a dirty hide are more likely to have large numbers of bacteria and hence more precaution should be taken when skinning. Antemortem inspection also assists in identifying zoonotic diseases if the animal is showing the clinical signs [35].

The major limitation in this study was low numbers or non-availability of cattle for slaughter in the abattoirs as this was likely to affect the sample size and time (seasonal change) for sample collection. However, this was resolved by contacting the abattoir management beforehand to get the schedules for slaughters in the abattoirs

\subsection{Conclusion}

The results generated from this study show that the microbial load of the fresh beef carcasses in Namwala district (a rural district) was higher than that in Lusaka district (an urban district). This could have been as a result of a number of multiplicative factors, significant among them being poor hygiene practices, such as wearing dirty working gear, lack of antemortem inspection and failure to fully implement HACCP in the production system. A high microbial load as determined by the TVC's was an indicator that beef was being produced under poor abattoir hygiene conditions. Therefore, beef carcasses with high bacterial loads are potential sources of food borne pathogens and likely to lead to food spoilage. Hence, there is need for advocating for good hygiene practices in the abattoirs.

Results from this study indicated that sound implementation of HACCP prerequisite programme is a more critical element in the hygienic dressing of carcasses. Given the paucity of data, with regard to the implementation of food safety and quality assurance system such as HACCP in abattoirs, the researchers can safely postulate that the problem of food contamination in most rural abattoirs could be significantly worse than recorded.

\section{Acknowledgements}

The researchers would like to thank all the members and staff of the microbiology laboratory in the Department of Disease Control, School of Veterinary Medicine. We would like to thank and express our gratitude to the management and all the staff at the abattoirs visited.

This research was carried out by the financial support obtained from Capacity Building in Zoonotic Diseases Management using the Integrated Approach to Ecosystems Health at Human-Livestock-Wildlife Interface in Eastern and Southern Africa (NORHED CAPAZOMANINTECO Grant Number UGA/130.

\section{References}

1. WHO. Estimates of the global burden of foodborne diseases. 2015 03.12.2015. Report No.

2. WHO, editor Developing and Maintaining Food Safetycontrol Systems for Africa Current Status and Prospects for Change2004; Bangkok, Thailand.

3. FAO. Milk and dairy products in human nutrition. Rome: 2013.

4. Mshana SE, Matee M, Rweyemamu M. Antimicrobial resistance in human and animal pathogens in Zambia, Democratic Republic of Congo, Mozambique and Tanzania: An urgent need of a sustainable surveillance system. Annals of clinical microbiology and antimicrobials. 2013;12(1):28.

5. Gracey JF. Meat hygiene: Baillière Tindall; 1986.

6. Antwi-Agyei P, Maalekuu 
B. Determination of microbial contamination in meat and fish products sold in the Kumasi metropolis (A case study of Kumasi central market and the Bantama market). Merit Research Journal of Agricultural Science and Soil Sciences. 2014;2[3]:38-46.

7. Korsak N, Daube G, Ghafir Y, Chahed A, Jolly S, Vindevogel H. An efficient sampling technique used to detect four foodborne pathogens on pork and beef carcasses in nine Belgian abattoirs. Journal of Food Protection ${ }^{\circledR}$. 1998;61[5]:535-41.

8. Bintsis T. Microbial pollution and food safety. AIMS Microbiol. 2018;4[3]:377-96.

9. Uçar A, Yilmaz MV, Cakiroglu F. Food Safety-problems and solutions. Significance, Prev Control Food Relat Dis. 2016:3-15.

10. Barros MdAF, Nero LA, Monteiro AA, Beloti V. Identification of main contamination points by hygiene indicator microorganisms in beef processing plants. Food Science and Technology (Campinas). 2007;27[4]:856-62.

11. CSO. Central Statistical Office labour force survey-Republic of Zambia. 2015.

12. World-Bank. What would it take for Zambia's beef and dairy industries to achieve their Potential? Finance and private sector development unit, Africa region. 2011 Report No. 62377-ZM.

13. CSO. Preliminary livestock and aquaculture census Results. Central Statistics Office, 2017.

14. Akinro A, Ologunagba I, Yahaya O. Environmental implications of unhygienic operation of a city abattoir in Akure, Western Nigeria. ARPN Journal of Engineering and Applied Sciences. 2009;4[9]:60-3.

15. Central Statistical Office $\mathrm{MoH}$, International I. Zambia demographic and health survey 2013-14. Central
Statistical Office, Ministry of Health, and ICF International; 2014.

16. C.D.C. Global health - Zambia Centers for disease control and prevention2019 [updated 17/06/2019]. Available from: https://http://www.cdc.gov/ globalhealth/countries/zambia/.

17. SES. Diarrheal Diseases in Zambia 2016. Available from: http://seszambia.com/diarrheal-diseaseszambia/.

18. Central Statistical Office/Zambia, Ministry of Health/Zambia, University of Zambia Teaching Hospital Virology Laboratory, University of Zambia Department of Population Studies, Tropical Diseases Research Centre/ Zambia, ICF International. Zambia Demographic and Health Survey 2013-14. Rockville, Maryland, USA: Central Statistical Office/ Zambia, Ministry of Health/ Zambia, and ICF International, 2015.

19. LCC. Change project for Kabesha abattoir "Healthy animals safe food". Lusaka City Coucil: Lusaka City Council, 2018.

20. FAO/RUAF. Assessing and planning the food system Lusaka, Zambia. Rome: Food and Agriculture Organization of the United Nation and RUAF Foundation, 2019 2019. Report No.

21. Muma JB. Application of hazard analysis critical control point (HACCP) concept to study cattle slaughterhouse hygiene and Carcass contamination in Zambia. 2008.

22. Jones RJ, Hussein HM, Zagorec M, Brightwell G, Tagg JR. Isolation of lactic acid bacteria with inhibitory activity against pathogens and spoilage organisms associated with fresh meat. Food Microbiology. 2008;25[2]:228-34.

23. Abreham S, Teklu A, Cox E, Sisay Tessema T. Escherichia coli 
O157:H7: distribution, molecular characterization, antimicrobial resistance patterns and source of contamination of sheep and goat carcasses at an export abattoir, Mojdo, Ethiopia. BMC microbiology. 2019;19(1):215-.

24. WheatleyP, Giotis ES, McKevitt AI. Effects of slaughtering operations on carcass contamination in an Irish pork production plant. Irish veterinary journal. 2014;67(1):1.

25. Mekonnen HHT, Kelali A,K S. Food safety knowledge and practices of abattoir and butchery shops and the microbial profile of meat in Mekelle City, Ethiopia. Asian Pacific Journal of Tropical Biomedicine. 2013;3[5]:407-12.

26. Heinz G, Hautzinger P. Meat Processing technology for small to medium scale producers. BANGKOK: FAO, 2010.

27. Galland JC. Risks and prevention of contamination of beef carcasses during the slaughter process in the United States of America 1997.

28. Galland J. Risks and prevention of contamination of beef carcasses during the slaughter process in the United States of America. Revue Scientifique et Technique-Office International des Epizooties. 1997;16[2]:395-404.

29. Parish M, Beuchat L, Suslow T, Harris L, Garrett E, Farber J, et al. Methods to reduce/eliminate pathogens from fresh and fresh-cut produce. Comprehensive reviews in food science and food safety. 2003;2(s1):161-73.

30. FAO/WHO. Guidance to governments on the application of HACCP in small and/or less-developed food businesses. USA: FAO/WHO, 2011.

31. Mirembe BB, Ndejjo R, Musoke D. Sanitation and hygiene status of butcheries in Kampala district, Uganda. African Journal of Food, Agriculture, Nutrition and
Development. 2015;15[3]:1015360.

32. Nel S, Lues JFR, Buys EM, Venter $\mathrm{P}$. The personal and general hygiene practices in the deboning room of a high throughput red meat abattoir. Food Control. 2004;15[7]:571-8.

33. Adzitey F, Teye G, Dinko M. Pre and post-slaughter animal handling by butchers in the Bawku Municipality of the Upper East Region of Ghana. Livest Res Rural Dev. 2011;23[2]:39.

34. Ntanga PD. Assessment of microbial contamination in beef from abattoir to retail meat outlets in Morogoro municipality, Tanzania: Sokoine University of Agriculture; 2013.

35. Buncic S, Nychas G-J, Lee MR, Koutsoumanis K, Hébraud M, Desvaux M, et al. Microbial pathogen control in the beef chain: recent research advances. Meat science. 2014;97[3]:288-97. 
Table 1: Mean Total Viable Counts $\left(\log _{10} \mathrm{cfu} / \mathrm{ml}\right)$ according to abattoirs

\begin{tabular}{cccc}
\hline Abattoir & No. Observations & Mean log cfu/ml & $\mathbf{9 5 \%}$ CI \\
\hline A & 50 & $4.93 \pm 0.85$ & $4.69-5.17$ \\
B & 24 & $4.69 \pm 0.81$ & $4.37-5.02$ \\
C & 134 & $5.64 \pm 0.65$ & $5.53-5.75$ \\
D & 106 & $4.55 \pm 0.61$ & $4.43-4.67$ \\
\hline
\end{tabular}

Table 2: Mean Aerobic Plate Counts $\left(\log 10 \mathrm{cfu} / \mathrm{cm}^{2}\right)$ at two processing points

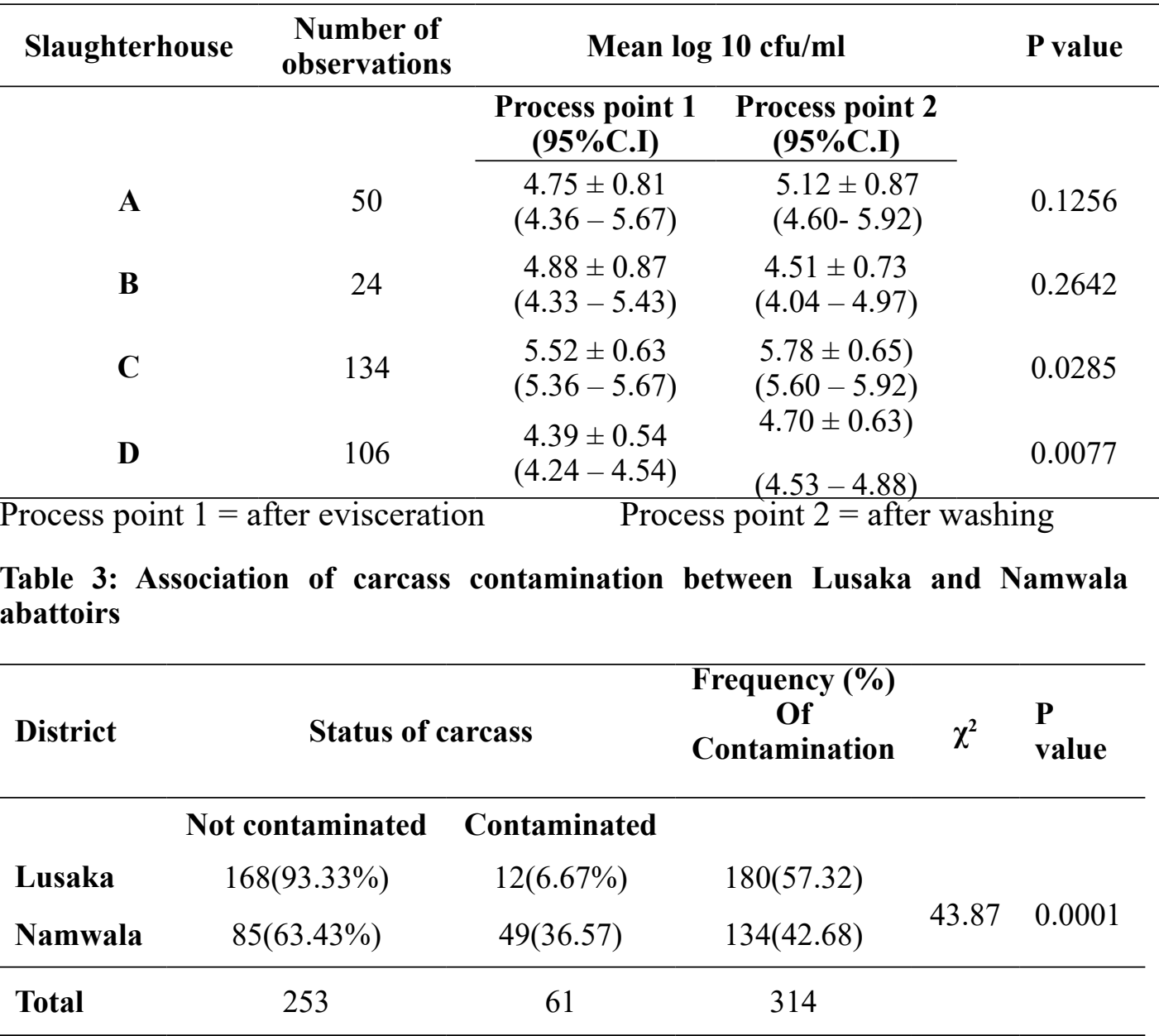


Table 4: Cross-tabulations of Risk factors for carcass contamination

\begin{tabular}{|c|c|c|c|c|c|c|}
\hline Region & & & & & $\chi^{2}$ & P value \\
\hline & \multicolumn{2}{|c|}{ Cleaning of work surface } & & & 40 & 0.0001 \\
\hline & $\begin{array}{l}\text { Once } \\
\text { everyday }\end{array}$ & $\begin{array}{l}\text { Before working } \\
\text { with every next } \\
\text { carcass }\end{array}$ & $\begin{array}{l}\text { Clean as you } \\
\text { work }\end{array}$ & & & \\
\hline Lusaka & 0 & $10(33.3)$ & $20(66.7)$ & $30(100)$ & & \\
\hline Namwala & $10(100)$ & 0 & 0 & $10(100)$ & & \\
\hline \multirow[t]{3}{*}{ Total } & $10[25]$ & $10[25]$ & $20(50)$ & 40 & & \\
\hline & \multicolumn{2}{|c|}{ Disinfection method used } & & & & \\
\hline & Chemical & $\begin{array}{l}\text { Hot water and } \\
\text { chemicals }\end{array}$ & Total & & 10.91 & 0.0001 \\
\hline Lusaka & $9[30]$ & $21(70)$ & $30(100)$ & & & \\
\hline Namwala & $9(90)$ & $1[10]$ & $10(100)$ & & & \\
\hline \multirow[t]{3}{*}{ Total } & $18(45)$ & $22(55)$ & 40 & & & \\
\hline & \multicolumn{3}{|c|}{ Performance of ante mortem inspection } & & & \\
\hline & Yes & No & Total & & & \\
\hline Lusaka & $20(66.7)$ & $10(33.3)$ & $30(100)$ & & 9.66 & 0.002 \\
\hline Namwala & $1[10]$ & $9(90)$ & $10(100)$ & & & \\
\hline \multirow[t]{3}{*}{ Total } & $21(52.5)$ & $19(47.5)$ & 40 & & & \\
\hline & \multicolumn{4}{|c|}{ Frequency of ante mortem inspection } & & \\
\hline & $\begin{array}{l}\text { Every day on } \\
\text { all animals } \\
\text { presented for } \\
\text { slaughter }\end{array}$ & $\begin{array}{l}\text { Randomly in a } \\
\text { week }\end{array}$ & $\begin{array}{c}\text { Not } \\
\text { performed }\end{array}$ & Total & 34.91 & 0.0001 \\
\hline Lusaka & $9[30]$ & 0 & $21(70)$ & $30(100)$ & & \\
\hline Namwala & 0 & $9(90)$ & $1[10]$ & $10(100)$ & & \\
\hline Total & $9(22.5)$ & $9(22.5)$ & $22(55)$ & 40 & & \\
\hline \multicolumn{5}{|c|}{ Composition of HACCP team } & 40.0 & 0.0001 \\
\hline & $\begin{array}{l}\text { Technical } \\
\text { officers only }\end{array}$ & $\begin{array}{l}\text { Technical officers } \\
\& \text { managers }\end{array}$ & $\begin{array}{l}\text { Technical } \\
\text { officers, } \\
\text { managers \& } \\
\text { food handlers }\end{array}$ & Total & & \\
\hline Lusaka & $10(33.3)$ & 0 & $20(66.7)$ & $30(100)$ & & \\
\hline Namwala & 0 & $10(100)$ & 0 & $10(100)$ & & \\
\hline Total & $10[25]$ & $10[25]$ & $20(50)$ & 40 & & \\
\hline \multicolumn{4}{|c|}{$\begin{array}{l}\text { Frequency of monitoring HACCP } \\
\text { Once }\end{array}$} & & 13.33 & 0.0001 \\
\hline & $\begin{array}{l}\text { Once per } \\
\text { quarter }\end{array}$ & $\begin{array}{l}\text { More than once per } \\
\text { quarter }\end{array}$ & & & & \\
\hline Lusaka & $10(33.3)$ & $20(66.7)$ & $30(100)$ & & & \\
\hline Namwala & $10(100)$ & 0 & $10(100)$ & & & \\
\hline Total & $20(50)$ & $20(50)$ & 40 & & & \\
\hline
\end{tabular}


Table 5: Results from the multivariable logistic regression model indicating significant factors related to contamination at abattoirs in Zambia.

\begin{tabular}{lcccccc}
\hline Variable & Level & $\boldsymbol{b}$ & SE(b) & P value & OR & $\begin{array}{c}\text { 95\% Conf. } \\
\text { Interval (OR) }\end{array}$ \\
\hline $\begin{array}{l}\text { Constant } \\
\begin{array}{l}\text { Types of } \\
\text { disinfection method } \\
\text { used }\end{array}\end{array}$ & 1.4 & 1.1 & 0.19 & & \\
& Hot water & 1.7 & 1.3 & 0.0043 & 7.6 & $3.3-9.6$ \\
& $\begin{array}{l}\text { Chemicals } \\
\text { Hot Water \& } \\
\text { Chemicals }\end{array}$ & & & & 1 & \\
\hline
\end{tabular}

Performance

$\begin{array}{lllllll}\text { of antemortem } & \text { Yes } & 1.2 & 1.1 & 0.009 & 2.8 & 1.4-4.9\end{array}$

inspection

No 1

Medical

examination of

abattoir workers

Yes

$\begin{array}{llll}1.5 & 1.3 & 0.01 \quad 6.51\end{array}$

4. $1-8.4$

abattoir workers

No

1

Wearing clean personal protective equipment

$\begin{array}{llllll}\text { Yes } & 0.5 & 0.4 & 0.04 & 1.1 & 0.29-1.3\end{array}$

No

1

Presence of the HACCP plan \& team in place

$\begin{array}{llllll}\text { Yes } & 1.9 & 1.5 & 0.0003 & 8.9 & 5.3-15.1\end{array}$

No 